\title{
The impact of outward FDI on the performance of Chinese firms
}

\author{
C. COZZA $^{\text {a }}$, R. RABELLOTTI ${ }^{\mathrm{b}}$, M. SANFILIPPO ${ }^{\mathrm{c}, *}$ \\ a University of Trieste, Italy \\ ${ }^{\mathrm{b}}$ University of Pavia, Italy \\ c University of Antwerp, Belgium
}

\section{A R T I C L E I N F O}

\section{Article history:}

Received 6 December 2014

Received in revised form 24 August 2015

Accepted 24 August 2015

Available online 1 September 2015

\section{JEL codes:}

F45

\section{Keywords:}

Outward FDI

Reverse spillovers

Performance

Acquisitions

Chinese multinationals

\begin{abstract}
A B S T R A C T
Using new firm-level data from the Emerging Multinationals' Events and Networks DATAbase (EMENDATA), this paper investigates the effects on Chinese firms of Outward FDI (OFDI) into advanced European countries. Propensity score matching is combined with a difference-indifference (DiD) estimator to reduce the problem of self-selection of treated firms in foreign markets, and to eliminate time-invariant and unobservable differences between those firms and the controls. The results provide robust evidence supporting the view that China's OFDI so far have had a positive impact on domestic activities in enhancing firms' productivity and scales of operation, measured by sales and employment. When we distinguish among investments on the basis of entry mode, accounting for endogeneity in the selection process, acquisitions facilitate early access to intangible assets, but are detrimental to financial performance, while greenfield investments have a stronger impact on the scale and productivity of Chinese multinationals investing in Europe.
\end{abstract}

(c) 2015 Elsevier Inc. All rights reserved.

\section{Introduction}

Outward Foreign Direct Investments (OFDIs) from China have become a popular topic in the academic literature because of their rapid increase and unconventional patterns (among many others, see Child and Rodrigues, 2005; Buckley et al., 2007). The rise of Chinese investments follows the provisions of the "Going Out" strategy, launched with the 10th Five-Year Plan in 2000 and reinforced in subsequent plans, which foster the internationalization of domestic firms. The aim is to promote industrialization and technological upgrading to support growth in the domestic economy (Gu and Reed, 2013). However, empirical research on the effect of OFDIs on the performance of Chinese investor companies is limited. The related empirical literature focuses mainly on analysing the drivers of internationalization and the location choices, at both country (Buckley et al., 2007; Deng, 2009) and firm levels (Amighini, Rabellotti \& Sanfilippo, 2013; Ramasamy, Yeung \& Laforet 2012). Some recent notable exceptions include a paper by Chen and Tang (2014) investigating the impact of Chinese OFDIs on firm performance, on the basis of data from the Chinese Ministry of Commerce, and a study by Edamura, Haneda, Inui, Tan \& Todo (2014), dealing with the impacts of acquisitions, based on a Chinese financial database (ChinaVenture).

In this paper, we investigate whether and how OFDIs have a positive impact on the performance of Chinese investing companies, analysing a sample of 368 Chinese investors with at least one affiliate in Europe, for the period 2003-2011. The empirical analysis is based on the new Emerging Multinationals' Events and Networks DATAbase (EMENDATA), which merges greenfield investments and mergers and acquisitions (M\&As) with firm level financial information from Bureau van Dijk's (BvD) Orbis.

\footnotetext{
* Corresponding author.

URL: marco.sanfilippo@uantwerp.be (M. Sanfilippo).
} 
We measure the impact of OFDIs on the investing companies, covering different dimensions of firm performance such as productivity, scale, sales and profitability. In addition, we disaggregate OFDIs according to mode of entry - M\&As or greenfield investments - assessing whether there is any difference in their impact on investors. To the best of our knowledge, this is the first study examining the impact of Chinese OFDIs (a) into advanced economies and (b) accounting for the specific effects of the different modes of entry.

Our geographical focus is on Europe, which receives $30 \%$ of all Chinese investments. ${ }^{1}$ It is an interesting destination also because Chinese OFDIs in EU countries are motivated mainly by the search for new markets aimed at creating overseas platforms for sales and distribution, and strategic assets to acquire foreign technologies, knowledge and brands that are not always fully available at home (Amighini et al., 2013). Therefore, it is of particular interest to investigate whether these investments - by introducing more efficient production techniques and improving the overall performance in terms of scale, sales and profitability - generate positive effects on the performance of the investing firms.

We use the propensity score matching (PSM) technique to investigate the impact of OFDIs on treated firms with one affiliate company in Europe, to compare them with a closely matched control group, selected from the subgroup of all the Chinese companies included in BvD Orbis with no investment abroad. We combine PSM with difference-in-difference (DiD) estimators to further eliminate time-invariant and unobservable differences between the treated and control firms.

Our results confirm that OFDIs have an impact on Chinese investors. We find a positive effect on efficiency and performance, which materializes at different points in time, and productivity enhancement which accrues over the long term (as in Mansfield, 1985 and Chen, Li \& Shapiro, 2012). We find an immediate impact on company size, indicated by an increase in the number of employees. Total sales also show an upsurge as a result of the investment, confirming the importance of market-seeking motives. Some interesting differences in these results occur if we distinguish investments by entry mode, taking into account the potential endogeneity of the choice. We find that acquisitions favour early access to intangible assets, but result in negative financial performance. However, Chinese firms are more likely to increase their size and sales via greenfield investments.

Our analysis has some important implications; it adds to existing knowledge on Chinese OFDIs, shedding new light on the spillovers resulting from the internationalization strategies in more advanced markets, and on which modes of entry better enable Chinese companies to gain competitive advantage.

The remainder of the paper is structured as follows. Section 2 reviews the literature on the effects of OFDIs on the performance of the investors. Section 3 presents the original data used for the analysis and discusses the methodology. The results are presented in Section 4 and Section 5 concludes.

\section{The effect of OFDIs on performance}

The nexus between OFDIs and investors' performance has been investigated mainly in an advanced economy context and has produced no clear-cut findings. Firms exploring foreign markets through FDIs can expect high returns, but also face large costs related to complexity, coordination and resource trade offs (Bertrand and Capron, 2014). The empirical literature on heterogeneous firms shows that typically MNEs enjoy productivity advantages over other types of firms (Helpman, Melitz \& Yeaple, 2004), but the evidence on other dimensions of performance, including employment and profitability, is less straightforward. Several studies show that both horizontal and vertical OFDIs generally have positive effects on productivity and on the size of their domestic activities (Barba Navaretti, Castellani \& Disdier, 2010; Desai, Foley \& Hines 2009), but the effects of vertical FDIs on employment are more ambiguous (Castellani and Barba Navaretti, 2004; Hijzen, Jean \& Mayer, 2011).

For emerging and developing countries, the empirical evidence on the impact of OFDIs on the investing firms is more limited. Unlike traditional MNEs, firms from emerging economies invest abroad in order to gain new competitive advantages and acquire lacking strategic resources (Ramamurti, 2012; Luo and Tung, 2007). Thus, it is not uncommon for emerging market MNEs (EMNEs) to undertake OFDIs as a deliberate growth strategy, increasing the overall scale of their activities (Luo and Tung, 2007).

Furthermore, both the motivations for and the final destination of the investments have an important influence on performance. This is pertinent to the present study, which focuses on OFDIs from emerging economies into advanced countries, characterized by a prevalence of market- and strategic asset-seeking motivations (Amighini et al., 2013).

In the case of market-seeking FDI, the resulting increase in the scope of operations of EMNEs may enable exploitation of economies of scale for both the parent and affiliate companies. This might be the consequence of sharing sunk costs or information, or learning by doing (Hijzen et al., 2011). In addition, economies of scale may have a significant impact on the performance of the parent company, which may provide both specialized services and intermediate goods to the affiliate, if the affiliate is involved in overseas production activities to serve foreign markets. In this context, the overall size of the EMNE will increase, and domestic and foreign production will combine to enhance productivity and competitiveness in both the home and host countries (Herzer, 2012; Desai et al., 2009).

The effects are potentially stronger in the case of asset- or technology-seeking FDI, which usually are directed to advanced economies, ${ }^{2}$ and are frequent among EMNEs. In this case, the foreign affiliate can be considered a vehicle for acquiring knowledge, technologies, know-how and management capabilities, all of which assets are then transmitted back to the parent company in the form of reverse technology and knowledge transfers (Chen et al., 2012). However, in some circumstances the potential

\footnotetext{
${ }^{1}$ Europe is the second most important destination for Chinese investments after Asia, accounting for almost 40\% of total OFDIs (based on EMENDATA). If Chinese investments to Hong Kong (11.5\%) are excluded, Europe is the main destination (Chaminade, 2015).

2 The MNE literature shows that the investment destination matters, with increases in productivity being associated with investments in higher technology intensive countries (de la Potterie and Lichtenberg, 2001; Barba Navaretti et al., 2010).
} 
benefits of such investments might be offset by the EMNE's lack of international experience (Bertrand and Capron, 2014; Buckley et al., 2014).

Among the few studies investigating the effects of OFDIs on the performance of EMNEs, some look specifically at the effect of an asset-seeking motive on the technological performance of the investing firm (Chen et al., 2012; Pradhan and Singh, 2009). A very small number of them focus on the effects of OFDIs on other aspects of firm performance in the context of emerging economies. Among these, a paper by Debaere, Lee \& Lee (2010) combines propensity score matching with DiD estimators to study the effect of FDIs on employment growth in a group of Korean MNEs, and shows significant reductions for firms investing in developing countries, but insignificant effects for investments in advanced economies. Two studies focus on Taiwan and show that foreign operations generally: a) promote an increase in domestic production and employment, conditional on the size of the investment (Liu and Nunnenkamp, 2011); and b) raise firm productivity through their effect on both the firm's technological endowments and its technical efficiency (Yang, Chen \& Huang, 2013).

A recent study by Chen and Tang (2014) investigates the effect of OFDIs on different dimensions of Chinese firms' performance. The paper is based on MOFCOM approved investments ${ }^{3}$ and finds positive effects of OFDIs on productivity, employment and various dimensions of export performance. In the present paper, we focus on Chinese investments in advanced economies and include information on investment entry mode. In principle, the efficiency gains and learning from FDIs could be captured equally through M\&As and greenfield investments, although in practise it is more likely that acquisitions contribute most to learning and knowledge transfer while greenfield FDIs are more likely to enhance complementarities (Bertrand and Capron, 2014).

In the context of EMNEs, to our knowledge no previous studies have examined the effect of greenfield FDI on firm performance, and very few evaluate the impact of M\&As. These latter include Edamura et al. (2014), which shows empirically the existence of a positive effects for Chinese investors on sales, productivity and assets, from M\&As, using a sample of public listed firms. However, there is also evidence suggesting that EMNEs may lack the internal capability needed to complete efficient acquisition deals (Nair et al., 2015). This is consistent with the findings in Bertrand and Betschinger (2012) on a sample of Russian MNEs. They look at the effects of acquisitions on profitability and find that lack of international experience combined with limited ownership advantages, undermine the capacity to leverage value from the foreign acquisition. This is confirmed by several case studies of Chinese EMNEs which show that the expected positive outcomes of M\&As in advanced countries are often postponed or reduced because of lack of experience and competitive advantage, especially in contexts characterized by wide cultural differences (Nolan, 2012; Spigarelli et al., 2013; Hansen et al., 2014).

\section{Data and methodology}

\subsection{The database}

Our analysis is based on a novel database, EMENDATA, which provides information on greenfield investments, M\&As, and other minority investments (Amighini, Cozza, Rabellotti \& Sanfilippo, 2014). EMENDATA matches different commercial data sources: the Financial Times Group's fDiMarkets, which provides information on greenfield investments, Bureau van Dijk's (BvD) Zephyr and Thomson Reuter's SDC Platinum which provide information on M\&As and other minority investments (ownership shares of less than 50\%). EMENDATA includes all the FDIs included in these sources, from EMNEs in Europe, in the period 2003 to 2011. EMENDATA also includes financial information on the investing companies and their Global Ultimate Owners (GUO) taken from Orbis (BvD). ${ }^{4}$

In the present work, we focus on greenfield investments and majority (at least 50\% ownership share) M\&As undertaken by Chinese investors in the EU27 countries. The total number of Chinese companies with at least one investment in the EU27 is 521 (423 with one investment and 98 with more than one deal), but we have information on the parent company for only 368 companies (70\% of the initial sample), obtained by consolidating all the deals related to the same business group. ${ }^{5}$

With regard to investment destinations, Chinese investments in Europe tend to be quite concentrated with the top five locations (in order of relevance: Germany, UK, France, Netherlands and Italy) representing almost 78\% of the total. In terms of sectorial specialization, there are large differences, with a slight prevalence of industrial machinery (15\% of total projects) and electronics (12\%). However, Chinese investors generally target all the main sectors of specialization in the EU27.

Table 1 shows that $84 \%$ of Chinese FDIs are greenfield investments. The main destination is Germany, which accounts for $37 \%$ of all Chinese investments in the EU27 and shows a large predominance of greenfield investments. The UK is the second most important destination, followed by France.

\footnotetext{
${ }^{3}$ Chen and Tang acknowledge that MOFCOM data are biased towards financial centres such as Hong Kong and, in many cases, the real final destination of the investments is unknown (for a comparison of the data used in our empirical analysis vs MOFCOM data see Amighini et al., 2014).

${ }^{4}$ Detailed information on EMENDATA is available in Amighini et al. (2014) and Chaminade (2015).

${ }^{5}$ With the exception of a small number of firms for which consolidated balance sheets are not available, consolidated financial statements are used for the empirical analysis.
} 
Table 1

Chinese FDIs in EU27 (\# 2003-2011).

Source: EMENDATA

\begin{tabular}{lrcc}
\hline Countries & Deals & Greenfield investments & M\&As \\
\hline Germany & 300 & 268 & 32 \\
UK & 136 & 108 & 28 \\
France & 70 & 50 & 32 \\
Netherlands & 49 & 33 & 17 \\
Italy & 44 & 182 & 11 \\
Other EU27 & 205 & 673 & 24 \\
Total EU27 & 804 & 2092 & 623 \\
Total world & 2715 & \\
\hline
\end{tabular}

\subsection{The econometric methodology}

The literature shows that empirical assessment of the impact of OFDIs on their investors is characterised by problems of endogeneity and reverse causality (Helpman et al., 2004). There is a problem of self-selection because larger and more productive firms are more likely to undertake foreign investments. In other words, the better performance of MNEs with respect to firms without foreign investments might be independent of their decision to undertake such investment (Castellani and Barba Navaretti, 2004).

In order to address these problems, the first step in our analysis is to assess the existence of structural differences between the two groups of firms: the treated firms corresponding to those companies with investments in the EU27, and the control group of companies with no foreign investments. ${ }^{6}$

Table 2 presents the key characteristics of the treated and untreated companies, in the year before the first investment. The choice to consider the first investment in the EU27 is motivated by the fact that the decision to internationalize in an advanced market and become a multinational company represents a status change for the company. ${ }^{7}$ In the empirical analysis we investigate whether this decision has an impact on the firm's productivity and structural characteristics.

In order to assign counterfactual treatment dates to the firms included in the control group we follow the procedure described in Chari, Chen and Dominguez (2012). Specifically, we adopt the approach of proportional random investment time assignment. First, we identified the number of investments occurring in each calendar year from 2003 to 2011 and assigned the hypothetical treatment year to the companies in the control group in the same proportion as the investments in the treated group. Thus, since some $12 \%$ of all investments occurred in 2006 in our sample of investors, then $12 \%$ of all firms in the control group were assigned 2006 as the hypothetical treatment year.

Table 2 shows that there are significant differences between the two groups: the treated companies are younger, larger and more profitable than the companies in the control group.

The second step in the analysis is to further investigate the existence of heterogeneity among the sample firms using a simple ordinary least squares (OLS) regression to test the relationship among firm's characteristics, performance indicators and a dummy variable (OFDI) which takes the value 1 in the year of the first investment and the following years and 0 otherwise (i.e. if a firm first invested in Europe in 2006, it takes the value zero for the years 2003 to 2005, and 1 for 2006 to 2011). ${ }^{8}$

The model is:

$$
Y_{i, j, x, t}=\beta \mathrm{OFDI} I_{i, j, x, t}+\gamma_{j}+\delta_{x}+\rho_{t}+\varepsilon_{i, j, x, t}
$$

where $Y$ indicates the firm characteristics and productivity measures (see Appendix A for details) for firm $i$ in province $j$, sector $x$ and year $t$, while $\gamma_{\mathrm{j}}, \delta_{x}$, and $\rho_{t}$, are province, industry (2 digit codes of the ISIC Rev. 3 classification), and year effects, respectively.

Table 3 shows that the effects of investment are positive and significant with respect to productivity, sales and employment, but negative for financial performance, especially return on assets. ${ }^{9}$

In the third step of the empirical analysis we follow a well-established strand of the empirical literature (Castellani and Barba Navaretti, 2004; Debaere et al., 2010) and use PSM to build a counterfactual by selecting a group of non-investors whose characteristics closely match those of the Chinese investing companies. Therefore, the control group includes Chinese companies with no foreign affiliates, but with the same ex-ante probability to undertake an OFDI.

\footnotetext{
${ }^{6}$ The control group includes 4801 Chinese companies with at least one subsidiary in China, but no foreign subsidiaries. They were selected from BvD's Orbis.

${ }^{7}$ In $63 \%$ of greenfield investments and $82 \%$ of M\&As, the companies had no previous experience of investment in any country. In 78\% of greenfield and $95 \%$ of M\&A investment the companies had no experience of investment in another advanced country (i.e. Australia, Canada, Japan, Switzerland and the US).

${ }^{8}$ As suggested by Bertrand and Capron (2014), the adopted construction of the OFDI variable allows us to account for multiple investors, i.e. firms with investments in several years. In Section 4.2, we introduce specific robustness checks to take account of these occurrences. However, our approach has the limitation that the variable OFDI in the treated group takes the value 0 even if the company made an investment before 2003. This is due to lack of information in EMENDATA and particularly in one of the data sources (fDiMarkets), for the years before 2003. However, we are confident that this limitation does not significantly affect our results since the larger wave of foreign investments from China started only from the second half of the 2000s.

${ }^{9}$ The summary statistics and the correlation matrix for all the variables included in the different models are reported in Appendix Tables B1 and B2.
} 
Table 2

Structural characteristics of sample firms (year before investment).

Source: Authors' elaboration on EMENDATA and Bvd Orbis.

\begin{tabular}{lcccc}
\hline & Treated & Control & t-test & \# \\
\hline Year of establishment & 1997 & 212 & 1995 & $-2.5136^{*}$ \\
Employees (\#) & 23097.4 & 134 & 2202.96 & 1868 \\
Total assets (USD million) & 29,300 & 152 & 749 & 1295 \\
Sales (USD million) & 1530 & 140 & 234 & 1395 \\
Turnover (USD million) & 2350 & 150 & 251 & 1384 \\
Profit margin (\%) & 12.711 & 138 & 8.084 & $-7.8857^{* *}$ \\
\hline
\end{tabular}

$* \mathrm{p}<0.05$.

** $\mathrm{p}<0.01$.

We then estimate the probability of investing in Europe as a function of observable characteristics by means of a probit model:

$$
\operatorname{Prob}\left(\mathrm{OFDI}_{i, t}=1 \mid X_{i, t-1}\right)
$$

Our vector of observable characteristics, $X$, includes a number of standard variables that can affect the probability of investing overseas (see Debaere et al., 2010; Chari et al., 2012; Chen and Tang, 2014), including age and age squared, as proxies for the firm's experience, size (number of employees), capital intensity, and financial performance (measured by the return on assets), ${ }^{10}$ and a dummy variable equal to 1 if the firm is listed on the stock exchange (and 0 otherwise) as a proxy for the capacity to access financial capital. ${ }^{11}$ The specification also includes 2-digit industry dummies, to control for industry-specific performance and to take account of incentives and policies aimed at specific sectors, and provincial dummies based on the geographical distribution of firms within provinces and autonomous municipalities to control for the heterogeneity of local policies, which might affect the firm's decision to invest. Finally, we include year dummies to control for common shocks and business cycle fluctuations.

The results of the probit model, reported in Table B3 in the Appendix B, show that larger firms, in terms of employment, capital intensiveness and higher returns on assets are more likely to invest in Europe. As in Edamura et al. (2014), age appears to have a negative effect, explained by the high propensity of Chinese MNEs to undertake early internationalization strategies and, thus, to leapfrog the traditional stages of development. However, the relation between age and the propensity to invest in advanced countries is non-linear, indicating that the most recently established firms have a lower probability of internationalizing.

Propensity scores are computed based on the output of the probit analysis. We select firms that are as much similar as possible to the investing companies in terms of their propensity score, using the Kernel matching estimator with common support provided by the Leuven and Sianesi (2003) algorithm. ${ }^{12}$

Fig. 1 depicts the matching procedure. The left side graph shows the predicted probability, that is, the propensity score, of investing abroad, for the entire control group before matching vis-à-vis the treated firms; the right side graph presents the same probability for the groups of matched controls and treated. We observe that, after the matching procedure, the two distributions almost overlap.

Another way to evaluate the results of the matching procedures is to test the so-called balancing hypothesis, meaning that observations with the same score have the same distribution of observable characteristics independent of treatment. This hypothesis is tested both before and after matching. Table 4 shows that the two samples can be considered well balanced since the standardized percentage bias falls well below the standard 5\% threshold, and that the t-tests on the selected variables are not significant (Rosenbaum and Rubin, 1983. Furthermore, following Sianesi (2004), we compare the pseudo $\mathrm{R}^{2}$ before and after the matching and find the expected reduction. ${ }^{13}$

Finally, in the fourth step of our empirical analysis, we use the propensity scores to calculate a DiD estimator to further rule out time-invariant and unobservable differences between treated and control firms, adopting the following general specification:

$$
Y_{i}=\beta_{0}+\beta_{1} t_{i}+\beta_{2} \text { treated }_{i}+\beta_{3} \text { treated }_{i} * t_{i}+\gamma_{j}+\delta_{x}+\rho_{t}+\varepsilon_{i}
$$

where firms in the control group are weighted on the basis of the propensity score, obtained via the matching procedure described earlier. The DiD allows comparison of the change in the average outcomes for the two groups of firms in our sample during a time period that includes one year before the investment $(t=-1)$ and a time period $(t=n)$ after it. Given the availability of a relatively long time series, we are able to test the effects on performance from the year of the investment $(t=0)$ and up to five years after $(t=5)$.

\footnotetext{
${ }^{10}$ For capital intensity and financial performance we include the average values of the 3 years before the investment. There are two main reasons for this choice: (1) it allows us to increase the number of observations given the large number of missing values in our sample; (2) the decision to invest might not be taken in the year before the investment on this, see Hijzen et al., 2011), especially if - as is the case in China - approval procedures are prolonged.

11 The choice of the control variables for the probit model was affected by data availability. It would have been interesting to include other variables to measure firms' internationalization status, R\&D expenditure and other financial information. We also could not account for being a state owned enterprises because this information is not directly available in our database or the original data sources.

12 A total 139 firms are included in the final treated group, and 1096 in the control group. Alternative matching algorithms, including nearest neighbour and Mahalanobis, were also tested, but their performance was worse in terms of the balancing test.

13 Since the pseudo $\mathrm{R}^{2}$ is an indicator of how well the regressors explain the probability of selection, after matching, its value should decrease considerably (Sianesi, 2004).
} 
Table 3

Determinants of firms' performance.

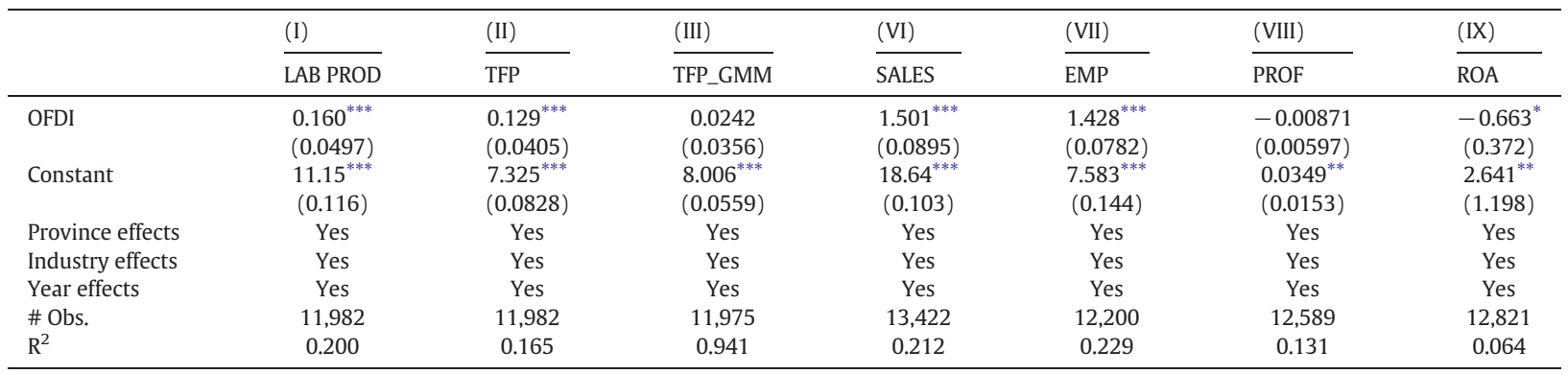

Note: LAB PROD is the log of Labour Productivity measured as the ratio of sales on employees; TFP is the log of Total Factor Productivity measured using the constant market share approach (see Appendix A); TFP_GMM is TFP measured using the GMM approach (see Appendix A); SALES is the log of total sales; EMP is the log of total employment; PROFIT is the profit margin (\%); and ROA is the return on assets (defined as EBIT over total assets). All the dependent variables are sourced from BvD Orbis. Robust standard errors in parentheses;

* $\mathrm{p}<0.1$.

** $\mathrm{p}<0.05$.

*** $\mathrm{p}<0.01$.

\section{Results}

Table 5 provides the results of our DiD estimator including a number of indicators over a period going from the year of the investment $(t=0)$ up to five years $(t=1, \ldots, 5)$ after it.

Columns I-III present the effects of the investments on firms' efficiency, showing that they do not induce a significant immediate increase in productivity. The sign of the coefficient (although still not significant) switches from positive at $t=0$ to negative for the following two years. The positive sign at $t=0$ can be considered confirmation of the existence of a productivity premium for foreign investors, as indicated in the previous section. The switch to a negative sign from $t=1$ can be interpreted as an initial effect of the investment due to the high costs linked to greater complexity and adaptation, especially for firms from emerging economies, which often are characterized by limited resources and few competitive advantages (Sanfilippo, 2015; Nair et al., 2015). Then, four years after the investment, Chinese firms investing in Europe experience a significant increase in their productivity, estimated to be in the range of 20-58 percentage points higher than for non-treated firms, depending on the indicator used. There are two possible explanations for this positive and significant difference in productivity. First, it might be the result of a reorganization of production activities, leading to a more efficient division of labour between parent and affiliates. Second, we can expect intra-firm transfer of knowledge, technologies and managerial best practise, which provides learning opportunities and reverse spillovers. The latter mechanisms depend on the existence of a knowledge gap between the host and home markets, which is likely in the China-EU case, and on the existence of absorptive capacities and a domestic environment conducive to knowledge transfer (Bertrand and Capron, 2014). Since an environment conducive to knowledge transfer may be weak in the case of China, we show that, on average, it takes four years for the productivity gains to be absorbed by the investing firm (Mansfield, 1985; Chen et al., 2012).

Related to this, in Column IV, we control for intangible assets as a proxy for asset-seeking motives (Deng, 2009; Buckley et al., 2014). One of the reasons why EMNEs invest abroad, especially in advanced markets, is to complement their resources with assets
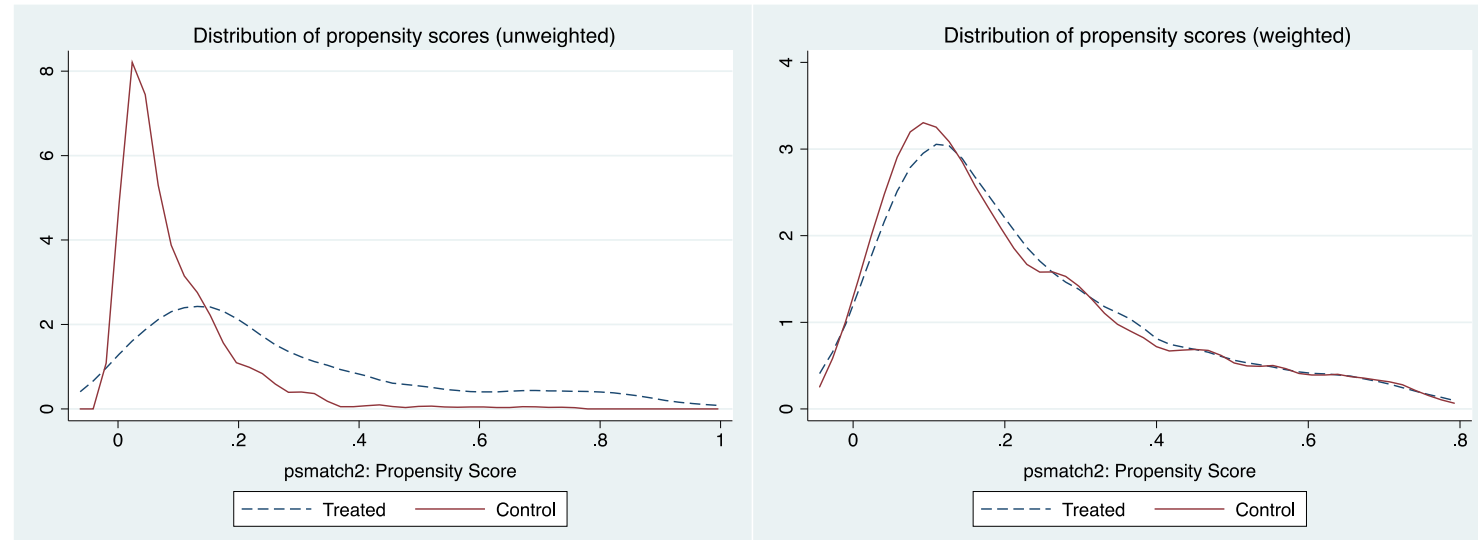

Source: Authors' elaboration

Fig. 1. Distribution of propensity scores before (left panel) and after (right panel) matching. Source: Authors' elaboration. 
Table 4

Balancing test, before and after matching.

\begin{tabular}{|c|c|c|c|c|c|c|c|}
\hline \multirow[b]{2}{*}{ Variable } & & \multicolumn{2}{|c|}{ Mean } & \multicolumn{2}{|c|}{ \% Reduction } & \multicolumn{2}{|c|}{ t-test } \\
\hline & & Treated & Control & $\%$ Bias & |Bias | & $\mathrm{p}>\mathrm{t}$ & $p>|t|$ \\
\hline \multirow[t]{2}{*}{ AGE } & Unmatched & 2.1409 & 2.3528 & -27.8 & \multirow[b]{2}{*}{81.9} & -12.50 & 0.000 \\
\hline & Matched & 2.12 & 2.0808 & 5 & & 0.43 & 0.669 \\
\hline \multirow[t]{2}{*}{ AGE2 } & Unmatched & 5.3061 & 6.0581 & -21.4 & \multirow[b]{2}{*}{78.9} & -9.39 & 0.000 \\
\hline & Matched & 5.0265 & 4.8679 & 4.5 & & 0.39 & 0.697 \\
\hline \multirow[t]{2}{*}{ EMPL } & Unmatched & 7.3231 & 6.7263 & 30 & \multirow{2}{*}{63.9} & 13.35 & 0.000 \\
\hline & Matched & 7.0673 & 6.8521 & 10.8 & & 0.88 & 0.378 \\
\hline \multirow[t]{2}{*}{$\mathrm{K} / \mathrm{E}$} & Unmatched & 11.718 & 11.547 & 11.7 & \multirow{2}{*}{36.2} & 4.81 & 0.000 \\
\hline & Matched & 11.699 & 11.589 & 7.5 & & 0.58 & 0.563 \\
\hline \multirow[t]{2}{*}{ ROA } & Unmatched & 7.8838 & 5.9605 & 19.6 & \multirow{2}{*}{97.1} & 7.06 & 0.000 \\
\hline & Matched & 8.0526 & 7.9969 & 0.6 & & 0.05 & 0.963 \\
\hline \multirow[t]{2}{*}{ Public } & Unmatched & 0.49861 & 0.56104 & -12.5 & \multirow{2}{*}{66.4} & -5.52 & 0.000 \\
\hline & Matched & 0.58594 & 0.56499 & 4.2 & & 0.34 & \\
\hline Sample & Pseudo $\mathrm{R}^{2}$ & \multicolumn{2}{|c|}{ LR chi2 } & $\mathrm{p}>$ chi 2 & \multicolumn{2}{|c|}{ Mean bias } & Median bias \\
\hline Raw & 0.183 & \multicolumn{2}{|c|}{1382.49} & 0.000 & \multicolumn{2}{|c|}{8.3} & 6.3 \\
\hline Matched & 0.022 & \multicolumn{2}{|c|}{7.76} & 1.000 & \multicolumn{2}{|c|}{2} & 0.5 \\
\hline
\end{tabular}

Note: AGE is the age of the firm (in log); EMP is the log of total employment (average for the 3 years before the investment); K/E is the capital (total assets) per employees ratio (in log) (average for the 3 years before the investment); ROA is the return on assets (defined as EBIT over total assets - average for the 3 years before the investment); and PUBLIC is a dummy variable measuring whether the firm is publicly listed or not. All the variables are sourced from BvD Orbis.

that are scarce in the home country (Ramamurti, 2012). However, we find no significant improvement relative to non-investors in the share of intangible over total assets, which, in fact, show a small relative decrease in years three and four, due possibly to more rapid accumulation of fixed assets, as shown by You and Solomon (2015) in a recent industry level analysis.

Table 5

Propensity score matching difference-in-difference estimator.

\begin{tabular}{|c|c|c|c|c|c|c|}
\hline \multirow[b]{2}{*}{$\mathrm{t}$} & \multicolumn{2}{|l|}{ (I) } & \multicolumn{2}{|l|}{ (II) } & \multicolumn{2}{|l|}{ (III) } \\
\hline & LAB PROD & $\mathrm{N}$ & TFP & $\mathrm{N}$ & TFP_GMM & $\mathrm{N}$ \\
\hline 0 & 0.0468 & 2122 & 0.0748 & 2122 & 0.0793 & 2122 \\
\hline 1 & -0.0328 & 1991 & -0.00888 & 1991 & -0.0397 & 1991 \\
\hline 2 & -0.0324 & 1707 & -0.0261 & 1707 & -0.127 & 1707 \\
\hline 3 & 0.154 & 1506 & 0.15 & 1506 & 0.0642 & 1506 \\
\hline 4 & $0.379^{* *}$ & 1349 & $0.307^{* *}$ & 1349 & $0.201^{*}$ & 1349 \\
\hline \multirow[t]{2}{*}{5} & $0.582^{* *}$ & 1259 & $0.469^{* * *}$ & 1259 & $0.292^{* *}$ & 1259 \\
\hline & \multicolumn{2}{|l|}{ (IV) } & \multicolumn{2}{|l|}{$(\mathrm{V})$} & \multicolumn{2}{|l|}{$(\mathrm{VI})$} \\
\hline $\mathrm{t}$ & INT/TOT & $\mathrm{N}$ & EMP & $\mathrm{N}$ & SALES & $\mathrm{N}$ \\
\hline 0 & 0.00498 & 1410 & $0.549^{* * *}$ & 2155 & $0.429^{* * *}$ & 2233 \\
\hline 1 & $1.31 \mathrm{E}-05$ & 1393 & $0.714^{* * *}$ & 2024 & $0.607^{* * *}$ & 2082 \\
\hline 2 & -0.00157 & 1208 & $1.094^{* * *}$ & 1735 & $0.962^{* * *}$ & 1816 \\
\hline 3 & $-0.0103^{*}$ & 1071 & $0.901 * * *$ & 1533 & $0.875^{* * *}$ & 1599 \\
\hline 4 & $-0.0183^{* *}$ & 952 & $0.853^{* * *}$ & 1373 & $1.025^{* * *}$ & 1414 \\
\hline 5 & -0.0126 & 858 & $1.019^{* * *}$ & 1282 & $1.600^{* * *}$ & 1272 \\
\hline
\end{tabular}

\begin{tabular}{|c|c|c|c|c|}
\hline \multirow[b]{2}{*}{$\mathrm{t}$} & \multicolumn{2}{|l|}{ (VII) } & \multicolumn{2}{|l|}{ (VIII) } \\
\hline & PROF & $\mathrm{N}$ & ROA & $\mathrm{N}$ \\
\hline 0 & -0.00921 & 1995 & -0.0623 & 2033 \\
\hline 1 & -0.0295 & 1862 & -1.025 & 1903 \\
\hline 2 & 0.00114 & 1605 & -0.226 & 1646 \\
\hline 3 & -0.0167 & 1418 & -0.182 & 1452 \\
\hline 4 & -0.0212 & 1285 & 0.0379 & 1312 \\
\hline 5 & -0.00574 & 1156 & -0.147 & 1185 \\
\hline
\end{tabular}

Note: This table reports difference-in-difference estimates for the post-investment performance between treated and control firms on different outcomes. All equations include province, sector and years fixed effects. $t=\{0,5\}$ denotes the post-investment year. LAB PROD is the log of Labour Productivity measured as the ratio of sales on employees; TFP is the log of Total Factor Productivity measured using the constant market share approach (see Appendix A); TFP_GMM is TFP measured using the GMM approach (see Appendix A); INT/TOT is the share of intangibles over total assets (\%); SALES is the log of total sales; EMP is the log of total employment; PROFIT is the profit margin (\%); and ROA is the return on assets (defined as EBIT over total assets). All the dependent variables are sourced from BvD Orbis.

Robust standard errors in parentheses.

* $\mathrm{p}<0.1$.

** $p<0.05$.

*** $\mathrm{p}<0.01$. 
Another important outcome of OFDIs is expansion in the overall scale of investors' activities. Although an investment represents an initial scale expansion for the investor, further increases can be due to various factors, such as, for instance, entry to new markets or expansion of existing activities across borders. We test this hypothesis in Columns V and VI.

In Table 5 Column V, we measure the impact of investments in Europe on employment in Chinese EMNEs and find a positive and significant effect. This result is consistent with existing evidence on the employment effect of OFDIs for Chinese firms (Chen and Tang, 2014) and firms in other emerging economies, such as Korea (Debaere et al., 2010) and Taiwan (Liu and Nunnenkamp, 2011). In the case of China, this result is not surprising. Since China is in the process of building domestic capacities, it is likely that efficiency seeking investments can be excluded, and that OFDIs will generally be oriented to increasing the scale of investor companies rather than substituting domestic employment by the establishment of foreign affiliates.

In similar vein, we find that investments lead to a significantly larger increase in total sales compared to the control group (Column VI). Unfortunately, due to data limitations, we cannot determine whether exports, intra-company trade or domestic sales explain this increase. Based on the literature on the determinants of Chinese FDIs (Buckley et al., 2007), we assume that such an increase might be explained by market seeking investments aimed at strengthening the relevant firms' market position in advanced countries through the establishment of trade offices and/or the acquisition of distribution networks. The importance of market seeking as a motivation for investment is also confirmed by surveys of Chinese investors in Europe (European Union Chamber of Commerce, 2013). Moreover, Chinese investments in advanced economies can be aimed at responding to the increasing sophistication of domestic demand, as documented in the case of the investments made by Haier, a Chinese white goods company with investments in Italy (Pietrobelli et al., 2011). This helps to explain the rise in domestic sales compared to national firms. Also, in the case of production related vertical investments, there might also be an increase in intra-firm trade (Barba Navaretti and Venables, 2004).

Finally, Columns VII-VIII in Table 5 report the impact of OFDIs on financial indicators to investigate how the profitability of the investor is affected by OFDI. The results are always not significant. However, in the empirical analysis presented in the next section, which takes account of different investment entry modes, because of the different financial effort involved, the results are different (Norbäck and Persson, 2008).

\subsection{Does entry mode influence domestic performance?}

In this section, we replicate the empirical analysis presented in the previous section introducing a distinction between entry modes - greenfield versus M\&As - to explore whether there is a different impact on investors. The treated and control samples are selected similar to what was described in Section 3.1. An important methodological difference stands out, however. Adopting the same approach would have introduced potential bias in the results due to endogeneity in firms' entry mode choice since the decision to invest and decision over entry mode are likely to be taken together (Javorcik, 2004). To overcome this limitation, we estimate the decision on investment entry mode conditional on investment taking place, using a sample selection model. More precisely, we run a bivariate probit model with sample selection with two dependent variables: OFDI which takes the value of 1 if the firm decides to invest, and 0 otherwise (as in Eq. (2)); and OFDI_MA which takes the value of 1 if the firm chooses M\&A and 0 if it opts for a greenfield investment:

$$
\text { OFDI } M A_{i t}= \begin{cases}1 & \text { if } \text { OFDI }_{i>}>0 \\ 0 & \text { otherwise }\end{cases}
$$

To estimate (Eq. 4) we use the same set of characteristics affecting the choice to invest abroad (as in 2), but excluding the year dummy, which is less likely to influence the choice of entry mode. ${ }^{14}$

The results of the bivariate probit model are reported in Appendix Table B4, and are broadly in line with those reported in Table B3. Firms undertaking M\&As are younger, smaller, and less capital intensive compared to those involved in greenfield FDIs. Interestingly, the effect of public listing on the probability to choose entry via M\&A is positive and significant. M\&As usually require a large capital commitment, and public listed firms are more likely to have access to financial resources. This is especially true in the case of China, where access to credit is considered a binding constraint on potential (non-listed) investors (Sutherland and Ning, 2011).

Once the selection model is correctly specified, we apply procedures similar to those described in Section 3.2 to retrieve propensity scores and weights, which then are used in the DiD regressions.

Tables 6 and 7 present the results of this analysis.

Columns I-III in Tables 6 and 7 show that both greenfield and M\&A FDIs result in increased productivity for Chinese EMNEs. This provides new evidence with respect to the analysis in Edamura et al. (2014), which focuses only on M\&As. Greenfield investments can result in early and higher productivity gains compared to M\&As, which may be the result of stronger complementarities with foreign affiliates. In contrast, strategic acquisitions by Chinese firms are more likely to be aimed at getting access to resources, which mainly are oriented to increasing the value added rather than the efficiency of production. It is also true that - especially in more distant contexts such as the EU27 for China - M\&As are more complex to manage than greenfield investments, which can result in underperforming deals. Indeed, in some cases, lack of prior international experience of many Chinese firms, and their cultural distance

\footnotetext{
14 For the model to be correctly identified, the selection equation should include at least one variable that is not in the probit equation. We estimate the model in two steps, computing the Inverse Mill's ratio after running the first probit model, and including its coefficient in the second equation. Due to the large number of dummies, which prevents convergence, we cannot estimate the two equations simultaneously using the "heckprob" routine in STATA. To check robustness, we ran a restricted model, including only the industry and provincial dummies, and obtained very similar results (reported in Appendix Table B3 Column II).
} 
Table 6

Results for propensity score matching difference-in-difference estimator (Greenfield).

\begin{tabular}{|c|c|c|c|c|c|c|c|}
\hline \multirow[b]{2}{*}{$\mathrm{t}$} & \multicolumn{2}{|l|}{ (I) } & \multicolumn{2}{|l|}{ (II) } & & \multicolumn{2}{|l|}{ (III) } \\
\hline & \multicolumn{2}{|l|}{ LAB PROD } & TFP & $\mathrm{N}$ & & TFP_GMM & $\mathrm{N}$ \\
\hline 0 & \multicolumn{2}{|l|}{$0.329^{*}$} & 0.234 & 1615 & & 0.0792 & 1615 \\
\hline 1 & \multicolumn{2}{|l|}{0.148} & 0.0595 & 1601 & & -0.144 & 1601 \\
\hline 2 & \multicolumn{2}{|l|}{0.0784} & 0.0204 & 1466 & & -0.126 & 1466 \\
\hline 3 & \multicolumn{2}{|l|}{0.201} & 0.0941 & 1293 & & -0.0955 & 1293 \\
\hline 4 & \multicolumn{2}{|l|}{$0.572^{* *}$} & $0.441^{* *}$ & 1160 & & 0.183 & 1160 \\
\hline \multirow[t]{2}{*}{5} & \multicolumn{2}{|l|}{$0.507^{* *}$} & $0.384^{* *}$ & 1060 & & 0.153 & 1060 \\
\hline & \multicolumn{2}{|l|}{ (IV) } & \multicolumn{2}{|l|}{$(\mathrm{V})$} & & \multicolumn{2}{|l|}{$(\mathrm{VI})$} \\
\hline $\mathrm{t}$ & INT/TOT & $\mathrm{N}$ & EMP & $\mathrm{N}$ & & SALES & $\mathrm{N}$ \\
\hline 0 & -0.0125 & 1134 & 0.352 & 1643 & & $0.487^{*}$ & 1742 \\
\hline 1 & 0.00226 & 1168 & $0.609^{* *}$ & 1628 & & $0.709^{* *}$ & 1704 \\
\hline 2 & -0.0167 & 1056 & 0.383 & 1493 & & 0.369 & 1561 \\
\hline 3 & -0.0151 & 923 & $0.839^{* *}$ & 1318 & & $1.008^{* *}$ & 1376 \\
\hline 4 & -0.0148 & 825 & $1.205^{* * * *}$ & 1181 & & $1.776^{* * *}$ & 1234 \\
\hline \multirow[t]{2}{*}{5} & -0.0208 & 750 & $1.053^{* *}$ & 1080 & & $1.560^{* * *}$ & 1113 \\
\hline & \multicolumn{3}{|c|}{ (VII) } & & \multicolumn{3}{|l|}{ (VIII) } \\
\hline $\mathrm{t}$ & \multicolumn{2}{|c|}{ PROF } & $\mathrm{N}$ & & \multicolumn{2}{|l|}{ ROA } & $\mathrm{N}$ \\
\hline 0 & \multicolumn{2}{|c|}{-0.0081} & 1563 & & \multicolumn{2}{|l|}{-2.982} & 1593 \\
\hline 1 & \multicolumn{2}{|c|}{0.0166} & 1532 & & \multicolumn{2}{|l|}{-2.508} & 1562 \\
\hline 2 & \multicolumn{2}{|c|}{0.0285} & 1414 & & \multicolumn{2}{|l|}{-5.788} & 1439 \\
\hline 3 & \multicolumn{2}{|c|}{$0.0563^{* *}$} & 1246 & & \multicolumn{2}{|l|}{-1.568} & 1272 \\
\hline 4 & \multicolumn{2}{|c|}{0.00958} & 1119 & & \multicolumn{2}{|l|}{-3.407} & 1133 \\
\hline 5 & \multicolumn{2}{|c|}{0.0625} & 995 & & \multicolumn{2}{|l|}{0.587} & 1011 \\
\hline
\end{tabular}

Note: This table documents difference-in-difference estimates for the post-investment performance between treated and control firms on a different set of outcomes. All equations include province, sector and years fixed effects. $t=\{0,5\}$ denotes the post-investment year. LAB PROD is the log of Labour Productivity measured as the ratio of sales on employees; TFP is the log of Total Factor Productivity measured using the constant market share approach (see Appendix A); TFP_GMM is TFP measured using the GMM approach (see Appendix A); INT/TOT is the share of intangibles over total assets (\%); SALES is the log of total sales; EMP is the log of total employment; PROFIT is the profit margin (\%); and ROA is the return on assets (defined as EBIT over total assets). All the dependent variables are sourced from BvD Orbis.

Robust standard errors in parentheses.

* $\mathrm{p}<0$.

** $\mathrm{p}<0.05$.

*** $\mathrm{p}<0.01$.

from western companies, cast doubt on their ability to successfully benefit from their foreign operations. This has been documented in several case studies of acquisitions made in Europe, which show the difficulty involved in obtaining the expected gains through the production efficiency of the acquired company (Spigarelli et al., 2013), and also the obstacles to the transfer of knowledge and technology from the targeted firm to the acquirer (Hansen et al., 2014).

With regard to employment and sales, greenfield investments have significant and positive effects. This is as expected since setting up a new affiliate necessarily involves the duplication of existing activities. However, since the majority of greenfield investments in Europe are small sized, ${ }^{15}$ we would also expect the large increase relative to domestic firms to go beyond the new activities created abroad and to positively affect the size of the investor. In relation to sales, given that some greenfield investments in Europe consist of the establishment of market-oriented and trade-related activities, their increase can be considered a confirmation of the positive impact of these internationalization strategies.

In the case of M\&As (Table 6), the impact on size is also generally positive and significant, but smaller than in the case of greenfield investments. Given that M\&As generally require higher cash flows and a more complex ex ante structure, firms investing via acquisitions, in general, tend to be companies that are better established in the home country, which may explain this relatively more limited impact on scale. In addition, since existing analyses linking the motivation of the investment to the entry mode show consistently that Chinese firms mainly use M\&As to gain access to strategic assets to upgrade their operations (Deng, 2009), while greenfield investments are used for expansion purposes (Quer et al., 2012), it could be argued that acquisitions should contribute mainly (and earlier) to qualitative rather than quantitative firm improvements.

In the case of intangible assets, we observe that Chinese firms increase their relative endowments as an immediate consequence of M\&As in Europe, which confirms the finding in Edamura et al. (2014) that it is mainly through acquisitions that Chinese firms tap into foreign technologies and knowledge to increase the pace of their upgrading (Deng, 2009).

Finally, the indicators of financial profitability weaken steadily as a consequence of M\&As. This result is consistent with the literature on the effects of M\&As. On the one hand, in line with Norbäck and Persson (2008), we confirm that negative profitability is more likely to be caused by M\&A than by greenfield investments. On the other hand, in line with Bertrand and Betschinger's (2012) finding

\footnotetext{
15 According to our data, about $75 \%$ of affiliates established through greenfield investments in Europe have fewer than 50 employees.
} 
Table 7

Results for propensity score matching difference-in-difference estimator (M\&As).

\begin{tabular}{|c|c|c|c|c|c|c|}
\hline \multirow[b]{2}{*}{$\mathrm{t}$} & \multicolumn{2}{|l|}{ (I) } & \multicolumn{2}{|l|}{ (II) } & \multicolumn{2}{|l|}{ (III) } \\
\hline & LAB PROD & $\mathrm{N}$ & TFP & $\mathrm{N}$ & TFP_GMM & $\mathrm{N}$ \\
\hline 0 & -0.0233 & 1558 & -0.0155 & 1558 & -0.048 & 1558 \\
\hline 1 & 0.16 & 1542 & 0.129 & 1542 & 0.0749 & 1542 \\
\hline 2 & 0.0982 & 1416 & 0.0477 & 1416 & -0.0222 & 1416 \\
\hline 3 & 0.0779 & 1284 & 0.0591 & 1284 & 0.0942 & 1284 \\
\hline 4 & $0.341^{*}$ & 1178 & $0.261^{*}$ & 1178 & $0.272^{* *}$ & 1178 \\
\hline \multirow[t]{2}{*}{5} & 0.223 & 1052 & 0.237 & 1052 & $0.315^{*}$ & 1052 \\
\hline & \multicolumn{2}{|l|}{ (IV) } & \multicolumn{2}{|l|}{$(\mathrm{V})$} & \multicolumn{2}{|l|}{ (VI) } \\
\hline $\mathrm{t}$ & INT/TOT & $\mathrm{N}$ & EMP & $\mathrm{N}$ & SALES & $\mathrm{N}$ \\
\hline 0 & $0.0215^{*}$ & 1134 & $0.615^{* *}$ & 1576 & $0.684^{*}$ & 1703 \\
\hline 1 & $0.0157^{*}$ & 1183 & $0.702^{* *}$ & 1558 & $0.673^{* *}$ & 1634 \\
\hline 2 & 0.0049 & 1020 & $0.678^{* *}$ & 1430 & $0.817^{* * * *}$ & 1506 \\
\hline 3 & -0.00562 & 938 & $0.517^{*}$ & 1299 & $0.632^{*}$ & 1400 \\
\hline 4 & 0.00694 & 861 & 0.258 & 1191 & $0.649^{*}$ & 1261 \\
\hline 5 & -0.0102 & 752 & -0.233 & 1065 & 0.203 & 1108 \\
\hline
\end{tabular}

(VI)

\begin{tabular}{|c|c|c|c|c|}
\hline \multirow[b]{2}{*}{$\mathrm{t}$} & \multicolumn{2}{|l|}{ (VI) } & \multicolumn{2}{|l|}{ (VII) } \\
\hline & PROF & $\mathrm{N}$ & ROA & $\mathrm{N}$ \\
\hline 0 & $-0.0476^{* *}$ & 1538 & -1.844 & 1568 \\
\hline 1 & $-0.0894^{* * *}$ & 1470 & $-2.493^{*}$ & 1498 \\
\hline 2 & $-0.0780^{* *}$ & 1333 & $-2.858^{*}$ & 1355 \\
\hline 3 & -0.0243 & 1254 & -1.711 & 1279 \\
\hline 4 & $-0.0651^{*}$ & 1138 & -1.229 & 1153 \\
\hline 5 & -0.0407 & 972 & -1.422 & 987 \\
\hline
\end{tabular}

Note: This table reports difference-in-difference estimates for post-investment performance between treated and control firms on a different set of outcomes. All equations include province, sector and years fixed effects. $t=\{0,5\}$ denotes the post-investment year. LAB PROD is the log of Labour Productivity measured as the ratio of sales on employees; TFP is the log of Total Factor Productivity measured using the constant market share approach (see Appendix A); TFP_GMM is TFP measured using the GMM approach (see Appendix A); INT/TOT is the share of intangibles over total assets (\%); SALES is the log of total sales; EMP is the log of total employment; PROFIT is the profit margin (\%); and ROA is the return on assets (defined as EBIT over total assets). All the dependent variables are sourced from BvD Orbis.

Robust standard errors in parentheses.

$* \mathrm{p}<0.1$.

** $\mathrm{p}<0.05$.

*** $\mathrm{p}<0.01$.

on M\&As undertaken by Russian MNEs, we show that Chinese MNEs (most in relation to their first foreign M\&A) are unable to leverage value from their foreign acquisitions.

\subsection{Robustness checks}

We ran a number of robustness checks to confirm the overall validity of our main findings. First, we verified that the results were robust to changes in the set of explanatory variables used in the Probit model. This has been done by replacing the control variables averaged for the last three years with their equivalents at time t and t-1, or by including a larger set of controls such as assets, turnover, and returns on efficiency. ${ }^{16}$ In both cases the results of the probit model (Appendix Table B3, Columns II-IV) and of the DiD remain largely unchanged, ${ }^{17}$ making us confident about their relevance and overall robustness.

In relation to the DiD results (Table 5), it could be argued that other characteristics might influence the performance of firms in combination with an OFDI. This applies especially to the productivity estimates; there is a large literature pointing to such variables as experience, size, internationalization status and innovative capacity as having a strong influence on firms' heterogeneous performance (Helpman et al., 2004). In order to address this potential concern, we ran the DiD model on the main measures of productivity reported in Table 4 Columns I-III, including age, size and capital intensity among the independent variables in the regressions. The results summarized in Appendix Table B5 are robust to the introduction of these additional controls. However, it is interesting to note that there is a reduction in the size of the effect of a FDI on the different measures of productivity, which might be attributable to the moderating effect of the covariates.

\subsubsection{Dealing with multiple treatments}

As mentioned in Section 3.2, the PSM estimator has several advantages over the standard procedures, and provides more clarity about the direction of causality between OFDI and performance, while taking account of related endogeneity issues. Nevertheless,

\footnotetext{
16 The introduction of these additional variables reduces the explanatory power of the model, and the balancing test run after the selection showed worse performance compared to our preferred specification. In addition, the introduction of total assets caused capital per employee to be dropped due to collinearity problems.

17 The DiD results are available upon request from the authors.
} 
this approach has attracted some criticism. One quite relevant point of contention is the issue of multiple treatments, that is, the presence of firms involved in multiple investments over the period considered. This could introduce biases into our estimations because, as indicated in Section 3.1, investors with more than one deal comprise $19 \%$ of the initial sample of 521 firms and increase to about $26 \%$ in the final sample of 368 investors.

While, as suggested by Bertrand and Capron (2014), our treatment indicator (OFDI) takes account of firms with more than one investment, the large size of the coefficients reported in Table 4, for some of the years after the initial investment, could be attributable to the effect of these additional investments.

In what follows, we account for this potential bias in the results by adopting two different strategies. First, we run our PSM-DiD model on a sample of treated firms composed of individual investors only, that is, excluding all firms involved in more than one investment in the period considered. In Appendix Table B6 shows that our concerns are not necessarily supported by the results since the relations examined remain significant. However, we see that the size of the scale-related coefficients (employees and sales) reduces as we move on to later years. In these cases, this could be explained by the exclusion from the sample of multiple investors.

Second, following the empirical strategy adopted by Bertrand and Betschinger (2012), we check the overall robustness of our approach by adopting an alternative estimator, based on a dynamic Generalized Method of Moments (GMM). In order to account for the presence of multiple investors, we replace our OFDI dummy with a new variable (N_OFDI) which counts the number of investments undertaken by each firm. In our settings, the GMM is a good alternative to the PSM approach, given that it takes account of the endogeneity of OFDI. It also controls for the possibility of omitted variables. This enables us to overcome the potential limitations due to the assumption of conditional independence in PSM (Imbens and Wooldridge, 2009). Finally, adopting a dynamic panel approach has the additional advantage of controlling for persistence, that is, the dependence of performance indicators on their past values.

We control for factors affecting the performance of both investors and non-investors to isolate the effect of FDIs, using a system GMM approach (Roodman, 2009) to test the effects of FDI on productivity. ${ }^{18}$ It is possible to infer from Table 8 that both the Hansen test of over-identification and the Arellano-Bond (Arellano and Bond, 1991) test of first and second order autocorrelation confirm the adequateness of the GMM specification adopted here. These results point again to the positive relation between investment and productivity, proved by the positive and significant coefficient of the N_OFDI variable. Compared to the previous results (Table 2), the coefficient of the FDI variable is higher since we account explicitly for the presence of multiple investors in the sample of treated firms.

\section{Conclusions}

This paper analysed the effects of OFDI into the EU-27 countries, on the performance of Chinese MNEs. Our results are robust and show that Chinese OFDIs so far have affected different dimensions of MNEs performance. We find that Chinese investors register an increase in productivity, but the effect materializes only some years after the initial investment. In line with the existing literature on EMNEs, we show also that the process of gaining access to new resources and intangible assets via M\&As may be accelerated, although at the cost of lower profitability. We show that M\&As are less frequently aimed at quantitative growth per se, and more on qualitative firm improvements. Indeed, firms engaging in M\&As are expected to be relatively larger ex ante, but to grow more slowly after the acquisition since their efforts are concentrated on the assimilation of technological advantages. Conversely, Chinese firms undertaking internationalization via greenfield investments experience greater complementarities between domestic and foreign activities, the former benefitting from significant increases in scale and sales.

Taken together, these results provide new evidence that the recent rise in Chinese investments, spurred by its government's strategy of promoting the internationalization of domestic firms, is leading to improved performance in the domestic sector. However, it is still difficult to say whether these performance improvements will contribute to the upgrading of China's productive structure. We found only weak evidence that M\&As are leading to the transfer of more valuable resources, in the form of intangible assets, to the parent companies making the investments, and found that this effect disappears a few years after the deal is concluded. In addition, due to the lack of information on value added, we were unable to investigate whether the productivity gains have lead to any process or product upgrading.

An implication of our work in relation to China's upgrading is that Chinese MNEs are still in the process of learning from their internationalization processes and, especially in the case of M\&As, are acquiring experience by accessing geographical and culturally distant markets. On the basis of our results, we can reasonably contend that the stock of accumulated experience in overseas investments is directly related to an increase in the size of the gains accruing to domestic firms. This can be interpreted as an encouraging sign for Chinese investors whose relative inexperience and lack of key competitive advantages have so far constrained their capacity to fully exploit the potential of overseas activities, and for the Chinese economy as a whole which could well expect large returns from its increasing OFDI activities.

This study has some limitations, which should be addressed in future research. The main shortcoming is related to the (un)availability of financial information for Chinese firms. Not only is this information missing for a number of the firms in our sample, where it is available, we found missing information, which constrained our analysis, and limited our ability to explore important dimensions such as exports and innovation. We were forced to rely on proxies for many indicators, such as TFP, due to lack of information on value added and intermediate inputs, among other things. Accessing new sources of firm level information would allow a more comprehensive evaluation of whether and through which mechanisms Chinese firms upgrade through OFDI.

\footnotetext{
${ }^{18}$ This choice is justified by the presence of a number of standard control variables (size, capital intensity, age), whose inclusion in the models to estimate other performance indicators, such as size, sales and profitability, would be unlikely.
} 
Table 8

System GMM estimator.*

\begin{tabular}{llll}
\hline & $(\mathrm{I})$ & $(\mathrm{II})$ & \multicolumn{1}{c}{ (III) } \\
\cline { 2 - 3 } & LAB PROD & TFP_GMM & $0.5688^{* * *}$ \\
\hline L1. & $0.4478^{* * * *}$ & $0.5493^{* * *}$ & {$[0.043]$} \\
N_OFDI & {$[0.045]$} & {$[0.042]^{* * *}$} & $0.0841^{* *}$ \\
AGE & $0.1901^{* * *}$ & $0.1549^{* * *}$ & {$[0.042]$} \\
& {$[0.037]$} & {$[0.033]$} & -0.0313 \\
EMPL & -0.0196 & -0.0162 & {$[0.107]$} \\
K/E & {$[0.016]$} & {$[0.014]$} & $-0.0368^{* * *}$ \\
& $-0.1046^{* * *}$ & $-0.0816^{* * *}$ & {$[0.018]$} \\
Constant & {$[0.022]$} & {$[0.021]$} & $-0.1421^{* *}$ \\
& $0.3632^{* * *}$ & $0.1392^{* * *}$ & {$[0.069]$} \\
Province effects & {$[0.030]$} & {$[0.017]$} & $5.5438^{* * *}$ \\
Industry effects & $2.8787^{* * *}$ & $2.4034^{* * *}$ & {$[1.161]$} \\
Year effects & {$[0.430]$} & {$[0.387]$} & Yes \\
Observations & Yes & Yes & Yes \\
No. of panels & Yes & Yes & Yes \\
Hansen & Yes & Yes & 9701 \\
AR2 & 9705 & 9705 & 2069 \\
\hline
\end{tabular}

Note: This table reports the results of the System GMM estimator on the full sample of controls and treated firms on different measures of productivity. LAB PROD is the log of Labour Productivity measured as the ratio of sales on employees; TFP is the log of Total Factor Productivity measured using the constant market share approach (see Appendix A); TFP_GMM is TFP measured using the GMM approach (see Appendix A). L1. is the first lag of the dependent variable; N_OFDI is the number of investments for firms-years; AGE is the log of a firm's age; EMPL is the log of the number of employees; and K/E is the ratio of capital (total assets) on labour. All variables except N_OFDI are sourced from BvD Orbis. In each model, only the variables L1, OFDI and N_OFDI are treated as endogenous and instrumented by the other dependent variables, including fixed effects.

Robust standard errors in parentheses.

$* \mathrm{p}<0.1$.

** $\mathrm{p}<0.05$

*** $\mathrm{p}<0.01$

\section{Acknowledgements}

We would like to thank two anonymous referees, Linke Zhu, and participants at the conference "Industrial upgrading and urbanization" held at the Stockholm School of Economics, for their helpful suggestions on a previous draft. Marco Sanfilippo thanks the Bank of Finland Institute for Economies in Transition (BOFIT) for support during the initial stages of this research project while visiting the Institute. Cozza and Rabellotti thank the Riksbankens Jubileumsfond for financial support.

\section{Appendix A}

The following indicators of productivity are used in the empirical analysis.

1) A standard indicator of firm efficiency in the form of labour productivity, measured as the ratio of sales to number of employees (LAB PROD).

2) An indicator of total factor productivity (TFP):

$$
Y_{i t}=A_{i t} L_{i t}^{\alpha_{L}} K_{i t}^{\alpha_{K}}
$$

in which $A_{i t}$ is the Hicks-neutral efficiency level that represents the firm's TFP. Total sales are used to proxy for output $(Y)$; number of employees is used as the labour component $(L)$ and total assets ${ }^{19}$ measures capital $(K)$. All the variables reported in monetary terms are deflated by their respective industry price indexes. We calculate TFP with a constant return to scale Cobb-Douglas production function, assuming a conventional share of two-thirds for the labour component and one-third for capital (for a discussion, see Hulten and Isaksson, 2007).

The insufficient number of observations to proxy for intermediate inputs does not allow us to calculate more robust semi-parametric estimators using proxies to correct for unobservable productivity shocks and input levels, such as the Olley-Pakes or Levinshon-Petrin methods. Therefore, we also estimate TFP using the GMM approach (TFP_GMM) (Arellano and Bond, 1991), bearing in mind the concerns raised in the literature related to these methodologies (Van Beveren, 2012).

\footnotetext{
19 Total assets are used instead of fixed assets, given the presence of firms operating in the service sector, where intangibles are usually relevant.
} 


\section{Appendix B}

Table B1. Summary statistics.

\begin{tabular}{|c|c|c|c|c|c|}
\hline Variable & Obs & Mean & Std. dev. & Min & Max \\
\hline LAB_PROD & 11,991 & 11.2401 & 1.1719 & 3.2050 & 20.2823 \\
\hline TFP & 11,991 & 7.3224 & 0.9301 & -0.4101 & 13.8726 \\
\hline TFP_GMM & 11,984 & 2.0879 & 3.1555 & -16.3051 & 23.9412 \\
\hline $\mathrm{K} / \mathrm{L}$ & 12,172 & 11.7933 & 1.2678 & 7.0540 & 20.4665 \\
\hline TOT_ASSETS & 13,656 & 18.7257 & 1.8320 & 8.7566 & 28.3503 \\
\hline INT/TOT & 10,232 & 0.0503 & 0.0685 & -0.0013 & 0.8396 \\
\hline EMPL & 12,209 & 6.9931 & 1.6071 & 0 & 13.1010 \\
\hline SALES & 13,431 & 18.1672 & 1.7816 & 7.2226 & 26.3514 \\
\hline ROA & 12,830 & 5.6443 & 10.7362 & -97.9000 & 97.2200 \\
\hline PROFIT & 12,598 & 0.0879 & 0.1707 & -0.9972 & 1 \\
\hline AGE & 19,417 & 2.3369 & 0.7233 & 0 & 5.0106 \\
\hline PUBLIC & 20,586 & 0.5545 & 0.4970 & 0 & 1 \\
\hline
\end{tabular}

Table B2. Correlation matrix.

\begin{tabular}{|c|c|c|c|c|c|c|c|c|c|c|c|c|}
\hline & LAB_PROD & TFP & prod_GMM & $\mathrm{K} / \mathrm{L}$ & TOT_ASSETS & INTANG & EMPL & SALES & ROA & PROFIT & AGE & PUBLIC \\
\hline LAB_PROD & 1 & & & & & & & & & & & \\
\hline TFP & 0.9605 & 1 & & & & & & & & & & \\
\hline TFP_GMM & 0.1206 & 0.1854 & 1 & & & & & & & & & \\
\hline $\mathrm{K} / \mathrm{L}$ & 0.7782 & 0.5726 & -0.0633 & 1 & & & & & & & & \\
\hline TOT_ASSETS & 0.3368 & 0.2777 & 0.0283 & 0.3655 & 1 & & & & & & & \\
\hline INT/TOT & -0.1454 & -0.1456 & -0.0298 & -0.0998 & -0.0809 & 1 & & & & & & \\
\hline EMPL & -0.2963 & -0.1893 & 0.0776 & -0.4455 & 0.6705 & 0.0017 & 1 & & & & & \\
\hline SALES & 0.4537 & 0.5246 & 0.1604 & 0.1525 & 0.8716 & -0.1046 & 0.7167 & 1 & & & & \\
\hline ROA & 0.1089 & 0.1557 & 0.0841 & -0.0307 & -0.065 & -0.018 & -0.0381 & 0.044 & 1 & & & \\
\hline PROFIT & 0.0688 & 0.0176 & -0.0079 & 0.163 & 0.0331 & -0.0118 & -0.0981 & -0.0413 & 0.7363 & 1 & & \\
\hline AGE & 0.0492 & 0.029 & -0.0496 & 0.0794 & 0.1083 & 0.053 & 0.0409 & 0.0741 & -0.1164 & -0.0674 & 1 & \\
\hline PUBLIC & -0.0331 & -0.0764 & -0.0767 & 0.0748 & 0.2102 & 0.065 & 0.1426 & 0.1088 & -0.0172 & 0.0556 & 0.0742 & 1 \\
\hline
\end{tabular}

Table B3. Probit model.

\begin{tabular}{|c|c|c|c|c|}
\hline & (I) & (II) & (III) & (IV) \\
\hline AGE & $\begin{array}{c}-1.361^{* * * *} \\
(0.288)\end{array}$ & $\begin{array}{c}-1.296^{* * *} \\
(0.308)\end{array}$ & $\begin{array}{c}-2.101^{* * *} \\
(0.402)\end{array}$ & $\begin{array}{c}-1.359^{* * *} \\
(0.288)\end{array}$ \\
\hline $\mathrm{AGE}^{2}$ & $\begin{array}{l}.199^{* * * *} \\
(.0617)\end{array}$ & $\begin{array}{l}0.200^{\text {**** }} \\
(0.0672)\end{array}$ & $\begin{array}{l}0.345^{\text {**** }} \\
(0.0811)\end{array}$ & $\begin{array}{l}0.198^{* * *} \\
(0.0618)\end{array}$ \\
\hline EMPL & $\begin{array}{l}.126^{* * *} \\
(.0399)\end{array}$ & $\begin{array}{l}0.187^{* * * *} \\
(0.0432)\end{array}$ & $\begin{array}{l}0.0959^{* *} \\
(0.0456)\end{array}$ & $\begin{array}{c}0.0435 \\
(0.0606)\end{array}$ \\
\hline $\mathrm{K} / \mathrm{L}$ & $\begin{array}{c}.082 \\
(.05344)\end{array}$ & $\begin{array}{c}0.110^{*} \\
(0.0602)\end{array}$ & $\begin{array}{c}-0.00809 \\
(0.0664)\end{array}$ & \\
\hline ROA & $\begin{array}{l}.0134^{* *} \\
(.0061)\end{array}$ & $\begin{array}{c}0.0134^{* *} \\
(0.00646)\end{array}$ & $\begin{array}{c}0.0124^{*} \\
(0.00633)\end{array}$ & $\begin{array}{c}0.0144^{*} \\
(0.00773)\end{array}$ \\
\hline Public & $\begin{array}{c}-.062 \\
(.1319)\end{array}$ & $\begin{array}{c}-0.0275 \\
(0.152)\end{array}$ & $\begin{array}{c}-0.0199 \\
(0.156)\end{array}$ & $\begin{array}{c}-0.0646 \\
(0.133)\end{array}$ \\
\hline Assets & & & & $\begin{array}{c}0.0834 \\
(0.0786)\end{array}$ \\
\hline Turnover & & & & $\begin{array}{c}-0.00233 \\
(0.0792)\end{array}$ \\
\hline ROE & & & & $\begin{array}{c}-0.000688 \\
(0.00192)\end{array}$ \\
\hline Province effects & Yes & Yes & Yes & Yes \\
\hline Industry effects & Yes & Yes & Yes & Yes \\
\hline Year effects & Yes & Yes & Yes & Yes \\
\hline Constant & $-6.332^{* * *}$ & -6.013 & -2.678 & -5.129 \\
\hline Observations & 1235 & 1049 & 957 & 1213 \\
\hline Pseudo $\mathrm{R}^{2}$ & .2005 & .2145 & .2105 & .1967 \\
\hline
\end{tabular}

Standard errors in parentheses.

* $\mathrm{p}<0.1$.

** $\mathrm{p}<0.05$.

*** $\mathrm{p}<0.01$. 
Table B4. Bivariate probit model with sample selection.*

\begin{tabular}{|c|c|c|}
\hline & (I) & (II) \\
\hline & OFDI_MA & OFDI_MA \\
\hline AGE & $\begin{array}{l}0.956^{* * *} \\
(0.365)\end{array}$ & $\begin{array}{l}0.360^{* *} \\
(0.160)\end{array}$ \\
\hline $\mathrm{AGE}^{\wedge} 2$ & $\begin{array}{l}-0.101 \\
(0.0744)\end{array}$ & $\begin{array}{l}-0.0511 \\
(0.0367)\end{array}$ \\
\hline EMPL & $\begin{array}{l}-0.408^{* * *} \\
(0.0893)\end{array}$ & $\begin{array}{l}-0.111^{* * *} \\
(0.0254)\end{array}$ \\
\hline K_E & $\begin{array}{l}-0.374^{* * *} \\
(0.0990)\end{array}$ & $\begin{array}{l}-0.0793^{* *} \\
(0.0319)\end{array}$ \\
\hline ROA & $\begin{array}{l}0.00476 \\
(0.0139)\end{array}$ & $\begin{array}{l}-0.0231^{\text {**** }} \\
(0.00521)\end{array}$ \\
\hline Public & $\begin{array}{l}3.224^{* * *} \\
(0.402)\end{array}$ & $\begin{array}{l}1.179^{* * *} \\
(0.151)\end{array}$ \\
\hline Constant & $\begin{array}{l}1.871 \\
(165.1)\end{array}$ & $\begin{array}{l}1.058 \\
(0.647)\end{array}$ \\
\hline $\begin{array}{l}\text { Observations } \\
\text { LR test (p-value) }\end{array}$ & 814 & $\begin{array}{l}1095 \\
14.89(0.0000)\end{array}$ \\
\hline
\end{tabular}

Standard errors in parenthesis.

Note: OFDI_MA, the dependent variable of the latent model, takes the value of 1 if the firm undertook a M\&A, and 0 if it undertook a greenfield FDI. Column I includes the results obtained using the two stage Heckman selection model. Column II reports estimates for the two equations run simultaneously. The selection model in Column I does not include year dummies, and there are no dummies included in the model reported in Column II.

* $\mathrm{p}<0.1$.

** $\mathrm{p}<0.05$.

*** $\mathrm{p}<0.01$

Table B4. Propensity score matching difference-in-difference estimator with additional controls.

\begin{tabular}{|c|c|c|c|c|c|c|}
\hline $\mathrm{t}$ & LAB PROD & $\mathrm{N}$ & TFP & $\mathrm{N}$ & TFP_GMM & $\mathrm{N}$ \\
\hline 0 & 0.0949 & 2122 & 0.0949 & 2122 & $0.108 *$ & 2122 \\
\hline 1 & -0.0211 & 1991 & -0.0211 & 1991 & -0.0277 & 1991 \\
\hline 2 & -0.0342 & 1707 & -0.0342 & 1707 & -0.0648 & 1707 \\
\hline 3 & 0.114 & 1506 & 0.114 & 1506 & 0.0906 & 1506 \\
\hline 4 & $0.229^{* *}$ & 1349 & $0.229^{* *}$ & 1349 & $0.247^{* *}$ & 1349 \\
\hline 5 & $0.362^{* * *}$ & 1259 & $0.362^{* * *}$ & 1259 & $0.372^{* * *}$ & 1259 \\
\hline
\end{tabular}

Note: This table reports difference-in-difference estimates for the post-investment performance of treated and control firms, for a different set of outcomes. All equations include capital labour ratio (K/L), the log of firms' age and the log of firms' employees as additional controls, together with province, sector and year fixed effects. $\mathrm{t}=\{0,5\}$ denotes the post-investment year.

Robust standard errors in parentheses.

* $\mathrm{p}<0.1$.

** $\mathrm{p}<0.05$.

*** $\mathrm{p}<0.01$. 
Table B5. Results, propensity score matching difference-in-difference estimator - individual investors only.

\begin{tabular}{|c|c|c|c|c|c|c|}
\hline $\mathrm{t}$ & Lab_prod & $\mathrm{N}$ & TFP & $\mathrm{N}$ & TFP_GMM & $\mathrm{N}$ \\
\hline 0 & 0.109 & 1696 & $0.142^{*}$ & 1696 & 0.127 & 1696 \\
\hline 1 & 0.0423 & 1652 & 0.0393 & 1652 & -0.0307 & 1652 \\
\hline 2 & 0.0574 & 1458 & 0.0182 & 1458 & -0.0794 & 1458 \\
\hline 3 & 0.0562 & 1286 & 0.0379 & 1286 & 0.00317 & 1286 \\
\hline 4 & $0.312^{* *}$ & 1149 & $0.223^{*}$ & 1149 & 0.139 & 1149 \\
\hline 5 & $0.477^{* * *}$ & 1052 & $0.424^{* * *}$ & 1052 & $0.431^{* * *}$ & 1052 \\
\hline $\mathrm{t}$ & INT/TOT & $\mathrm{N}$ & Employees & $\mathrm{N}$ & Sales & $\mathrm{N}$ \\
\hline 0 & 0.00345 & 1189 & $0.493^{* * *}$ & 1720 & $0.484^{* * *}$ & 1834 \\
\hline 1 & 0.00242 & 1206 & $0.639^{* * *}$ & 1677 & $0.679^{* * *}$ & 1761 \\
\hline 2 & -0.000566 & 1045 & $0.898^{* * *}$ & 1479 & $0.774^{* * *}$ & 1554 \\
\hline 3 & -0.0122 & 920 & $0.657^{* * *}$ & 1310 & $0.524^{*}$ & 1359 \\
\hline 4 & -0.0061 & 813 & $0.736^{* *}$ & 1168 & $0.726^{* *}$ & 1211 \\
\hline 5 & -0.0152 & 738 & $0.709^{*}$ & 1069 & $0.649^{* *}$ & 1099 \\
\hline $\mathrm{t}$ & \multicolumn{2}{|c|}{ Profit } & $\mathrm{N}$ & \multicolumn{2}{|r|}{ ROA } & $\mathrm{N}$ \\
\hline 0 & \multicolumn{2}{|c|}{0.00224} & 1617 & \multicolumn{2}{|r|}{-0.358} & 1650 \\
\hline 1 & \multicolumn{2}{|c|}{-0.0206} & 1570 & \multicolumn{2}{|r|}{-0.436} & 1608 \\
\hline 2 & \multicolumn{2}{|c|}{0.00679} & 1400 & \multicolumn{2}{|r|}{-2.156} & 1425 \\
\hline 3 & \multicolumn{2}{|c|}{-0.00618} & 1214 & \multicolumn{2}{|r|}{-1.177} & 1241 \\
\hline 4 & \multicolumn{2}{|c|}{0.00353} & 1084 & \multicolumn{2}{|r|}{1.103} & 1104 \\
\hline 5 & \multicolumn{2}{|c|}{-0.00498} & 971 & \multicolumn{2}{|r|}{1.244} & 989 \\
\hline
\end{tabular}

Note: This table reports difference-in-difference estimates for post-investment performance of treated and control firms for a different set of outcomes. All equations include province, sector and year fixed effects. $t=\{0,5\}$ denotes the post-investment year.

Robust standard errors in parentheses.

* $\mathrm{p}<0.1$.

** $\mathrm{p}<0.05$.

*** $\mathrm{p}<0.01$.

\section{References}

Amighini, A., Cozza, C., Rabellotti, R., \& Sanfilippo, M. (2014). Investigating Chinese outward FDI: How can firm level data help? China E` World Economy, 22 (6), 44-63. Amighini, A., Rabellotti, R., \& Sanfilippo, M. (2013). Do Chinese state-owned and private enterprises differ in their internationalization strategies? China Economic Review, 27, 312-325.

Arellano, M., \& Bond, S. (1991). Some tests of specification for panel data: Monte Carlo evidence and an application to employment equations. Review of Economic Studies, 58, 277-297.

Barba Navaretti, G., \& Venables, A. J. (2004). Host country effects: Conceptual framework and the evidence. Multinational firms in the world economy (pp. 151-182). Princeton and Oxford: Princeton University Press.

Barba Navaretti, G., Castellani, D., \& Disdier, A. C. (2010). How does investing in cheap labour countries affect performance at home? Firm-level evidence from France and Italy. Oxford Economic Papers, 62(2010), 234-260.

Bertrand, O., \& Betschinger, M. (2012). Performance of domestic and cross-border acquisitions empirical evidence from Russian acquirers. Journal of Comparative Economics, 40, 413-437.

Bertrand, O., \& Capron, L. (2014). Productivity enhancement at home via cross-border acquisitions: The roles of learning and contemporaneous domestic investment. Strategic Management Journal. http://dx.doi.org/10.1002/smj.2256.

van Beveren, I. (2012). Total factor productivity estimation: A practical review. Journal of Economic Surveys, 26(1), 98-128.

Buckley, P. J., Clegg, L. J., Cross, A. R., Liu, X., Voss, H., \& Zheng, P. (2007). The determinants of Chinese outward foreign direct investment. Journal of International Business Studies, 38(4), 499-518.

Buckley, P. J., Elia, S., \& Kafouros, M. (2014). Acquisitions by emerging market multinationals: Implications for firm performance. Journal of World Business. http://dx. doi.org/10.1016/j.jwb.2013.12.013.

Castellani, D., \& Barba Navaretti, G. (2004). Investments abroad and performance at home: Evidence from Italian multinationals. CEPR discussion papers N. 4284.

Chaminade, C. (Ed.). (2015). Technology-driven FDI by Emerging Multinationals in Europe, project report. CIRCLE: Lund University available at https:// globalisationofinnovation.files.wordpress.com/2015/03/tfdi-by-emerging-multinationals-in-europe.pdf.

Chari, A., Chen, W., \& Dominguez, K. M. E. (2012). Foreign ownership and firm performance: Emerging market acquisitions in the United States. IMF Economic Review, $60,1-42$.

Chen, V. Z., Li, J., \& Shapiro, D. M. (2012). International reverse spillover effects on parent firms: Evidences from emerging-market MNEs in developed markets. European Management Journal, 30, 204-218.

Chen, W., \& Tang, H. (2014). The dragon is flying west: Micro-level evidence of Chinese outward direct investment. Asian Development Review, 31(2), 109-140.

Child, J., \& Rodrigues, S. B. (2005). The internationalization of Chinese firms: A case for theoretical extension? Management and Organization Review, 1(3), 381-410.

De La Potterie, B. V. P., \& Lichtenberg, F. (2001). Does foreign direct investment transfer technology across borders? Review of Economics and Statistics, 83(3), $490-497$.

Debaere, P., Lee, H., \& Lee, J. (2010). It matters where you go. Outward foreign direct investment and multinational employment growth at home. Journal of Development Economics, 91(2010), 301-309.

Deng, P. (2009). Why do Chinese firms tend to acquire strategic assets in international expansion? Journal of World Business, 44(4), 74-84.

Desai, M. A., Foley, C. F., \& Hines, J. R. (2009). Domestic effects of the foreign activities of US multinationals. American Economic Journal: Economic Policy, 1(1), 181-203.

Edamura, K., Haneda, S., Inui, T., Tan, H., \& Todo, Y. (2014). Impact of Chinese cross-border outbond M\&As on firm performance: Econometric analysis using firm-level data. China Economic Review, 30, 169-179.

European Union Chamber of Commerce in China (2013). Chinese outbond investments in the European Union. Shanghai: European Union Chamber of Commerce in China.

Gu, L., \& Reed, W. R. (2013). Chinese overseas M\&A performance and the go global policy. The Economics of Transition, 21(1), 157-192.

Hansen, U. E., Fold, N., \& Hansen, T. (2014). Upgrading to lead firm position via international acquisition: Learning from the global biomass power plant industry. Journal of Economic Geography. http://dx.doi.org/10.1093/jeg/lbu050. 
Helpman, E., Melitz, M., \& Yeaple, S. (2004). Export versus FDI with heterogeneous firms. American Economic Review, 94, $300-316$.

Herzer, D. (2012). Outward FDI, total factor productivity and domestic output: Evidence from Germany. International Economic Journal, 26(1), $155-174$.

Hijzen, A., Jean, S., \& Mayer, T. (2011). The effects at home of initiating production abroad: Evidence from matched French firms. Review of World Economics, 147, $457-483$.

Hulten, C. R., \& Isaksson, A. (2007). Why development levels differ: The sources of differential economic growth in a panel of high and low income countries. NBER working paper no. 13469.

Imbens, G., \& Wooldridge, J. M. (2009). Recent developments in the econometrics of program evaluation. Journal of Economic Literature, 47(1), 5-86.

Javorcik, B. S. (2004). The composition of foreign direct investment and protection of intellectual property rights: Evidence from transition economies. European Economic Review, 48(1), 39-62.

Leuven, E., \& Sianesi, B. (2003). |PSMATCH2: Stata module to perform full mahalanobis and propensity score matching, common support graphing, and covariate imbalance testing, software. http://ideas.repec.org/c/boc/bocode/s432001.html.

Liu, W. H., \& Nunnenkamp, P. (2011). Domestic repercussions of different types of FDI: Firm-level evidence for Taiwanese manufacturing. World Development, 39(5), $808-823$.

Luo, Y., \& Tung, L. R. (2007). International expansion of emerging market enterprises: A springboard perspective. Journal of International Business Studies, 38, 481-498.

Mansfield, E. (1985). How rapidly does new industrial technology leak out? The Journal of Industrial Economics, 217-223.

Nair, S. R., Demirbag, M., \& Mellahi, K. (2015). Reverse knowledge transfer in emerging market multinationals: The Indian context. International Business Review. http:// dx.doi.org/10.1016/j.ibusrev.2015.02.011.

Nolan, P. (2012). Is China buying the world? Cambridge (UK): Polity Press.

Norbäck, P. J., \& Persson, L. (2008). Globalization and profitability of cross-border mergers and acquisitions. Economic Theory, 35(2), $241-266$.

Pietrobelli, C., Rabellotti, R., \& Sanfilippo, M. (2011). Chinese FDI strategy in Italy: The 'Marco Polo' effect. International Journal of Technological Learning, Innovation and Development, 4(4), 277-291.

Pradhan, J. P., \& Singh, N. (2009). Outward FDI and knowledge flows: A study of the Indian automotive sector. International Journal of Institutions and Economies, 1(1), $156-187$.

Quer, D., Claver, E., and Riend, L. (2012) Chinese multinationals and entry mode choice: Institutional, transaction and firm-specific factors, Frontiers Business Research China, 6(1): 1-24.

Ramamurti, R. (2012). What is really different about emerging market multinationals? Global Strategy Journal, 2(1), 41-47.

Ramasamy, B., Yeung, M., \& Laforet, S. (2012). China's outward foreign direct investment: Location choice and firm ownership. Journal of World Business, 47(1), 17-25.

Roodman, D. (2009). How to do xtabond2: An introduction to difference and system GMM in stata. Stata Journal, 9(1).

Rosenbaum, P., \& Rubin, D. (1983). The central role of the propensity score in observational studies for causal effects. Biometrika, $70,41-55$.

Sanfilippo, M. (2015). FDI from emerging markets and the productivity gap - An analysis on affiliates of BRICS EMNEs in Europe. International Business Review, 24, 665-676.

Sianesi, B. (2004). An evaluation of the Swedish system of active labor market programs in the 1990s. Review of Economics and Statistics, 86(1), 133-155.

Spigarelli, F., Alon, I., \& Mucelli, A. (2013). Chinese overseas M\&A: Overcoming cultural and organizational divides. International Journal of Technological Learning, Innovation and Development, 6(1), 190-208.

Sutherland, D., \& Ning, L. (2011). Exploring ‘onward-journey’ ODI strategies in China's private sector businesses. Journal of Chinese Economics and Business Studies, 9(1), 43-65.

Yang, S. F., Chen, K. M., \& Huang, T. H. (2013). (2013) Outward foreign direct investment and technical efficiency: Evidence from Taiwan's manufacturing firms. Journal of Asian Economics, 27, 7-17.

You, K., \& Solomon, O. H. (2015). China's outward foreign direct investment and domestic investment: An industrial level analysis. China Economic Review. http://dx. doi.org/10.1016/j.chieco.2015.02.006. 